\section{Sprikende om lungemedisinens historie}

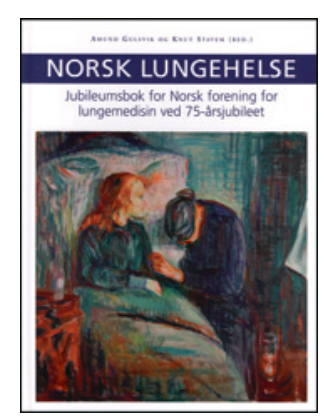

Amund Gulsvik, Knut Stavem, red.

Norsk lungehelse

Jubileumsbok for Norsk forening for lungemedisin ved 75-årsjubileet. 40 s, tab, ill. Oslo: Norsk forening for lungemedisin, 2012. Pris NOK 400

ISBN 978-82-303-2231-4

«Vi har ønsket å beskrive trekk i utviklingen fra opprinnelsen med fokus på tuberkulose til dagens subspesialitet innenfor indremedisin», skriver redaktørene i sitt forord til jubileumsskriftet. De sier videre at de ikke har klart å skille entydig mellom en historiebok og lærebok, og at de nok heller ikke har lyktes i å gi et kritisk blikk på norsk lungemedisin og synliggjøre hva som eventuelt gikk galt eller eventuelt kunne ha vært bedre. Anmelderen kan slutte seg til denne oppsummeringen.

Det er også blitt en flott bok, ikke minst utstyrsmessig, og det er flere gode enkeltbidrag som for en medisinhistoriker gir ny innsikt. Men fremstillingen henger på sett og vis ikke i hop. Med åtte deler, 53 underkapitler og 63 forfattere må det bli mange overlappinger og mange stemmer.

Som svar på endringer i sykdomspanoramaet og den medisinsktekniske og vitenskapelige utviklingen rundt forrige århundreskifte, meldte det seg blant leger flest et sterkt behov for fagutvikling og spesialisering. De mange foreningsdannelsene på denne tiden må ses i lys av dette. For lungelegenes del begynte det i 1903 med Legeforeningens tuberkulosekomité. Dernest ble en nordisk og så en norsk lungetuberkuloseforening etablert, henholdsvis i 1919 og 1926. Ti år senere, i 1936, kom det enda to foreninger: Norske lægers tuberkuloseselskap og Norske lungespesialisters forening, den første opptatt av forebygging, klinisk arbeid og vitenskap, den andre av arbeidsforhold og økonomi. Vanskelig å henge med? Enklere ble det i 1970 da de to sistnevnte ble slått sammen til dagens Norsk forening for lungemedisin, en organisasjon som $\mathrm{i}$ teorien favner alle lungelidelser.

Spesialitetens utvikling og krav er et annet tema i den første delen, blant annet om den kontroversielle overgangen i 1984 fra selvstendig spesialitet til indremedisinsk grenspesialitet. Frykt for tap av ressurser hevdes å være årsaken til motstanden, men kunne det ikke også handle om frykt for tap av synlighet og prestisje?

De mange delkapitlene i den første delen kunne med fordel vært skrevet sammen, og ikke minst sterkt forenklet. Nå finner vi en oppramsing av uendelige mange navn, navn som har mening for en begrenset leserkrets, og som kunne ha vært plassert i et vedlegg. Det samme gjelder oppramsingen av temaer i de faglige programmene på årsmøter og kongresser. Videre kunne programmene som gjenspeiler endringer $i$ arbeidsfeltet og således endringer i syk- domspanoramaet og profesjonsinteressene - blitt satt inn i en større sammenheng. Et sted påpeker forfatterne, ganske riktig, at de spesielle forholdene som tuberkulose og lungesykdommer generelt har frembudt, har gitt spesialiteten et særlig preg med nær tilknytning til generelle hygieniske og sosialmedisinske arbeidsoppgaver. En utdypning hadde vært fint.

Det som ellers slår leseren, er at i denne mannsverden av foreningsmedlemmer finner vi gjennom mange årtier kun én kvinne, Margrethe Folkestad ved Folkesanatoriet på Grefsen. Hun må ha vært en tøff dame.

Etter den første delen er boken delt opp i følgende deler: Endringer i sykdomspanorama, Diagnostisk utvikling, Terapeutisk utvikling, Norsk forskning i lungemedisin, Utdanning og internasjonal kontakt, Spesialisthelsetjenesten i 2012, Industriutvikling og til slutt et oppsummerende kapittel.

Av interessante og opplysende enkeltbidrag vil jeg nevne kapitlet om forandringer i sykdomspanoramaet (kapittel 12). Den dramatiske endringen i dette bildet - fra tuberkulosens dominans opp mot midten av 1900-tallet, til dagens astma, kronisk obstruktiv lungesykdom (kols), lungekreft, søvnrelaterte respirasjonsforstyrrelser m.v. - er et viktig tema som det er interessant å reflektere over, for eksempel knyttet til diskusjonen om hvorfor sykdommer kommer og går. Videre gir forfatterne i kapitlene 14 og 15, henholdsvis om moderne bakteriediagnostikk ved sykdommer i lungene og om bildediagnostikk av thorax, et godt innblikk i fremveksten av dagens metoder. Kapittel 23 er et tilbakeblikk på tuberkulosen de siste 25 årene og inneholder mye nyttig kunnskap. Vi har vel ant det, men ikke vært sikre på at Norge er ett av de landene i verden med minst tuberkulose, at nysmitte er meget sjelden, og også lavere enn i våre naboland. Men forekomsten har likevel økt med økende innvandring.

Det er mye interessant å finne i denne boken, og den vil utvilsomt være verdifull for folk i faget. Men den vil også være nyttig som grunnlag for en mer helhetlig fremstilling om lungemedisinens historie i norsk og internasjonal sammenheng.

\section{Aina Schiøtz}

Institutt for global helse og samfunnsmedisin

Universitetet i Bergen 